\title{
Enhancing the organisational commitment of public sector accounting staff through the pursuit of CSR objectives
}

Dr. Dermot C. McCarthy, Dr. Phyllis Alexander and Mr. Young Jung.

Business School, Bournemouth University, Fern Barrow, Poole, Dorset, BH12 5BB, UK

\begin{abstract}
Purpose: to examine the interrelationship between the employee public service motivations (PSM), organisational corporate social responsibility (CSR) objectives, and employee organisational commitment amongst accounts department staff in public service organisations.
\end{abstract}

Approach: survey data is taken from tax accountants and accounts administration staff $(\mathrm{n}=285)$ across seven South Korean state-owned enterprises involved in the provision of various public services (utilities, infrastructure, energy, and housing). SEM techniques are used to conduct a mediation and moderated-mediation analysis.

Findings: results show that both employee PSM and organisational CSR are significant in determining organisational commitment, especially where they result in value congruence. We also find that perceived levels of internal and external CSR are significant in moderating the impact of different dimensions of PSM.

Originality: little research has examined the relationship between PSM and organisational commitment amongst accounting staff in the quasi-public/private state-owned enterprise sector. This despite the level of organisational (e.g. introduction of NPM approach) and professional change (e.g. regulatory changes) experienced over the past two decades and the importance of the sector in public service provision.

Practical implications: As accounting in public service organisations faces growing professional and commercial demands to address stakeholder needs, the need for organisations to retain accounts staff with the necessary motivations is vital. Our findings highlight the importance of value congruence in achieving long-term employee organisational commitment, and the need for the CSR objectives of organisations to take account of both external and internal stakeholders.

Keywords: Organisational commitment, accounting, public service motivation, personorganisation fit, state-owned enterprise. 


\section{Introduction}

Research on the motivations of accounting staff working in the public sector is needed to improve levels of organisational commitment. There is a growing cost for organisations associated with accounting staff turnover, arising from additional recruitment costs and loss of staff with specialised skills and experience (McManus et al, 2014). Research on the personal and situational factors that determine levels of organisational commitment has been a feature of accounting research for some time (Ketchand and Strawser, 2001). Accounting staff have a strong need for achievement, which underscores the need for organisations to provide an environment that enables such needs to be met (Street and Bishop, 1991). These individual needs and the ability of public sector organisations to meet them has been much influenced by the rise of new public management approaches and a growing emphasis on social responsibility within industry and the accounting profession.

The introduction of new public management principles to public sector organisations has created a focus on competition, results-orientated behaviour, managerialism, and a need for accountability (Bracci et al, 2015). The subsequent growth in financial management has placed public service providers in what Olson et al. (2001) describes as an 'evaluatory trap', in which ever-decreasing public services are accompanied by ever-increasing service costs. This blurring of the line between the public and private sectors raises concerns around the ability of organisations to serve the public interest and meet the needs of their employees, many of whom join the public sector with the aim of satisfying personal altruistic needs and a desire to serve the needs of wider society (Perry and Wise, 1990). Nevertheless, there still exists basic differences in the operations and objectives pursued by public and private enterprises. Despite the growing requirements for public sector organisations to achieve efficiencies; their consumers, wider society and the state still relies on them for the provision of many important public services (Dittenhofer, 2001). 
Evidence suggests that accounting staff who choose to work for public sector organisations maintain a different set of values and expectations from their private sector counterparts (Brewer and Lam, 2009). Employees in the public sector can be characterised by greater levels of public service motivation (PSM); synonymous with compassion, selfsacrifice and a desire to serve the public interest (Houston, 2000). Enhanced public, state and media scrutiny of an increasingly transparent public sector adds weight to these issues. Accountancy research makes frequent reference to the conflict that can arise between the ideals of the accountancy profession on protecting the public interest and the more commercial objectives that may be pursued by their more commercialised employers (Bobek et al., 2017).

Over recent decades there has been a growing and evolving focus on firm outcomes for a broad range of stakeholders. Agudelo et al. (2019) provides a comprehensive literature review of the history and evolution of these issues under the concept of corporate social responsibility (CSR). This dynamic concept has been influenced by academic publications, governmental decisions (e.g. (de)regulation, legislation, creation of entities), and social and international movements (e.g. UN's Strategic Development Goals). CSR has evolved from a "decision making process in the 1980 s to a strategic necessity by the early 2000s" (Agudelo et al. 2019, p16). Changes in management accounting have resulted, including the move away from a narrow focus on economic performance and toward taking more account of social and environmental performance (Kelly and Alam, 2008). The emergence of environmental accounting and integrated reporting are products of this evolution, as the international community demands more transparency and accountability of private and public institutions. Internal decision-making is facilitated by these new management accounting practices; through a process of identifying, collecting, and analysing a broad range of CSR- 
related information on stakeholder and environmental outcomes (Schaltegger and Burritt, 2000).

For organisations with objectives that include CSR, the provision of timely and relevant information to varying managerial roles using robust accounting systems is an important issue (Schaltegger et al. 2015). The stakeholder objectives held by both organisations (i.e. CSR) and staff (i.e. PSM), along with their shared desire to enhance the organisation's image and reputation are a potentially important factor in creating and operationalising effective accounting systems (Bennett et al, 2013; Schaltegger and Burritt, 2000). For example, when Gray et al. (1995) considered the role of accountants in the early stages of formulating organisational environmental and sustainability conceptions and actions, they were found wanting. However, as environmental accounting and sustainability reporting evolved in the 2000s, it has become apparent that accountants can and do play a significant facilitating role (Bennett et al., 2013). Schaltegger and Zvezdov (2015), in examining the role of accountants in UK and German companies considered to be leading in sustainability reporting, concluded that accountants act as gatekeepers between sustainability managers and higher management.

Several studies have examined the merit of applying CSR accounting principles at the level of local government and the wider public sector (Qian et al, 2011; Farneti and Guthrie, 2009; Ball, 2005). Such research stems from the premise that "public entities are expected to lead by example in reporting publicly and transparently on their activities to promote sustainability" (Ribeiro et al., 2016, p353). In a recent study, Kaur and Lodhia (2018) emphasised the role of stakeholder engagement in effective sustainability and reporting practice amongst Australian local councils.

Alongside the above changes in private and public sector organisational objectives, developments within the accounting profession are also a salient issue. Professional 
accountants are self-regulated (e.g. ICAEW, ACCA, CIMA) and externally regulated (e.g. governmental agencies and/or their delegated independent agencies). The respective codes of conduct established by the various professional bodies, which are largely based on the International Ethics Standards Board for Accountants, underpins high quality service and public confidence. The accounting professional bodies recognise that accountants are well placed to make significant contributions in the gathering, analysing, reporting and externally assuring CSR information (Bennett et al., 2013 and Collins et al., 2011). Since 2013, public entities have been moving to integrated reporting where the CSR information is provided with the financial information in annual reports. While such information remains voluntary, it has become expected by stakeholders. The Integrated Reporting Council currently reports over 2,000 businesses in more than 70 countries have implemented such reporting (IIRC, 2020).

The formation of such deeply-held professional standards surrounding ethics, social responsibility and public interest can have a significant impact on the motivations with which accounting staff enter public sector organisations, encapsulated in their sense of PSM. The behaviour of such employees can be greatly influenced by the organisation's stated objectives or code-of-conduct on CSR, as well as by the related internal procedures, rules and training (Shafer, 2015). Given the important role of accounting professionals in managing competing stakeholder demands (i.e. shareholders, professional bodies, regulators) and facilitating internal decision-making, the motivations of accounting staff and how these motivations interact with those of their organisation are a salient issue. Yang et al. (2017) in considering innovations in green information systems, recognised the importance of both individual intrinsic motivation stemming from belief in environmental value, and extrinsic motivation based on compliance with institutional forces and regulation. Brockhaus et al. (2017) also recognised the need for organisations to be a 'true believer' in CSR objectives and 
operationalise such objectives through mainstream practice, to achieve and sustain highperforming capabilities.

This paper will contribute to this debate by examining the PSM of accountancy staff who choose to work within public sector enterprises, with focus on their altruistic needs and desire to provide public service. We align these individual motives with the perceived CSR objectives of the organisation and examine the consequences in terms of value-congruence and employee organisational commitment. The paper makes several contributions to existing accounting research. It is the first paper to provide a quantitative analysis of the alignment between the PSM of accounting staff and the CSR objectives of their organisation, an important issue that has gone unnoticed by existing accounting research. Secondly, the paper explores whether the alignment of individual PSM and the CSR objectives of their organisation work to create a more committed workforce in pursuit of shared stakeholder objectives. Finally, given the challenges faced by public-sector organisations in retaining professional accounting staff, findings on what measures can be taken to ensure the needs of employees are met will be of interest to not only researchers, but also to management within the sector.

The following section will examine in more detail the relationship between PSM and organisational commitment, and the role of value congruence as a mediating factor. We will then discuss the role perceived organisational CSR can play in moderating this relationship. The following sections will outline the method of data collection and analysis, which is divided into separate mediation and moderated-mediation models. The final two sections of the paper present our findings, before concluding with a discussion and a set of recommendations for practice and future research.

\section{The relationship between PSM and organisational commitment}


Figure 1 provides an outline of the model which will be examined in this paper. The focus of this model is on the relationship between the PSM of accounts department employees, whether such motivations arise intrinsically (e.g. self-sacrifice) or from external sources (e.g. professional training focused on public values), and their level of organisational commitment.

\section{Insert Figure 1 around here}

Organisational commitment can be defined as "a psychological state that (a) characterises the employee's relationship with the organisation, and (b) has implications for the decision to continue or discontinue membership of the organisation" (Meyer et al., 1993: p.539). Meyer and Allen (1991) classified three forms of organisational commitment, with affective commitment being most salient in determining employee performance and level of turnover (Meyer et al., 2002). This paper will focus on this form of organisational commitment, which can be defined as "affective or emotional attachment to the organisation such that the strongly committed individual identifies with, is involved in, and enjoys membership of the organisation" (Allen and Meyer, 1990: p.2).

Several studies have found that employee PSM can be a determinant of their organisational commitment (Moynihan and Pandey, 2007; Taylor, 2007). PSM refers to motivation arising from the altruistic and public service needs of employees. While employees in all sectors are motivated by a combination of material rewards and intangible psychological rewards, it can be expected that those who choose a career in the public sector will have a relatively greater desire to serve the public interest and help others, as opposed to maximising financial and other material rewards (Anderfuhren-Biget et al., 2010). The conceptualisation of PSM includes several sub-dimensions, including an employee's desire to participate in the formulation of public policy, to serve the public interest, to demonstrate compassion towards others, and a willingness to substitute personal rewards for service to 
others (Perry, 1996). In this paper we explore the relationship PSM as a combined concept, as well as each of its four sub-dimensions, has with organisational commitment.

In its attempt to understand the relationship between PSM and organisational commitment, extant literature has put forward arguments for both a direct and indirect relationship, with the latter having come to dominate through empirical testing. The concept of a psychological contract between employers and their employees is commonly used to explain the direct relationship between employee PSM and their organisational commitment (Coyle-Shapiro and Kessler, 2003; Rousseau, 1995). Under this view, employees with a high level of altruism and desire to serve the public interest (i.e. PSM) will demonstrate a higher level of organisational commitment within public sector organisations, as it is through public sector employment that they are provided with an opportunity to satisfy such individual needs. Existing accounting research lends some support to this view, finding that personal (e.g. ethical orientation) and situational factors (e.g. job and organisational characteristics) have a significant impact on organisational commitment (Curtis and Taylor, 2018; McManus et al., 2014), which in turn impacts greatly on outcomes such as turnover (Ketchand and Strawser, 2001).

While some empirical support has been found for a direct relationship between employee PSM and organisational commitment (Castaing, 2006), the evidence is far from conclusive (Moynihan and Pandey, 2007). Instead, arguments are put forward for an indirect relationship dependent on the degree to which the organisation is seen to support the public interest (Bright, 2013). Where employees feel their organisation's values are aligned with their own, they can be expected to demonstrate a greater level of organisational commitment (Wright and Pandey, 2008; Coursey et al., 2012). However, individuals with a high level of PSM may reduce their level of organisational commitment where the objectives pursued by their employer fails to align with their own (Wright \& Christensen, 2010). To take greater 
account of this issue, many researchers have included measures of value congruence such as person-organisation fit in their modelling of the PSM and organisational commitment relationship (Harari et al., 2017), as we have also done in figure 1. As a measure of value congruence, person-organisation fit is defined as "the compatibility between people and organisations that occurs when: (a) at least one entity provides what the other needs, or (b) they share similar fundamental characteristics, or (c) both" (Kristof, 1996: p.4-5). Chatman (1991) outlined the role person-organisation fit can play in determining organisational commitment through both selection and socialisation processes. Selection takes place at the point of recruitment and is the assessment of compatibility between the personally held values of the individual and those of the organisation. Socialisation refers to the process that takes place after the individual takes up their position and is how they come to understand the values and objectives of the organisation.

As a highly specialised profession, with strong professional institutions and guidance, accounting staff can face a trade-off between commitment to their profession and organisational commitment. The degree to which the objectives of the organisation align with those that arise professionally can be expected to overcome such trade-offs and enhance employee organisational commitment. When addressing the accounting profession, Smith and Hall (2008, p.76) concluded:

"Societies value committed professionals. Characteristics of a profession include controlling a defined body of knowledge, advanced education, a degree of autonomy over work practices, and an obligation to serve clients' best interests. In particular, some past research has argued that professionals distinguish themselves by making a commitment to serve the public good through their work and to approach their work with a degree of altruism." 
Several empirical studies have found person-organisation fit plays a significant mediating role between PSM and organisational commitment (Palma, 2016). However, this relationship is often only a partially mediated relationship (Teo et al., 2016). Furthermore, in their examination of data from 4,130 Dutch public employees, Steijn (2008) failed to find any mediating role by person-organisation fit in examining organisational commitment, work effort and job performance. As a result, there remains a need for this relationship to be further investigated. Furthermore, to date the issue has not been investigated in the context of staff working in the accounting profession. The above discussion gives rise to our first two research hypotheses:

H1: PSM will have a positive relationship with (specialist) employee organisational commitment.

H2: person-organisation fit mediates the relationship between PSM and (specialist) employee organisational commitment.

We want to examine not only the impact of PSM as a second order variable on organisational commitment, but we also want to examine the impact of each dimension of PSM (i.e. attraction to public policy, commitment to public values, compassion, selfsacrifice). The inclusion of PSM and its dimensions in analysis has been supported on the grounds that while the various dimensions are related, they are theoretically distinct and can therefore be expected to have differing impacts on outcome variables (Kim, 2018).

In Harari et al (2017)'s meta-analysis of 46 PSM studies, evidence was found of a difference between each dimension of PSM and their relationship with job satisfaction and organisational commitment. In a recent study, Kim (2017) used data from a sample of Korean civil servants to compare the impact across dimensions on job satisfaction, 
organisational commitment and person-organisation fit. While the findings showed no significant difference between the predictive capacities of the measures, there was a significant difference found between the relationship each had with employee outcomes. This gives rise to our next research hypothesis:

H3: Each dimension of PSM will have a positive relationship with employee organisational commitment.

\section{Role of CSR in moderating the PSM and organisational commitment relationship}

As outlined above, existing PSM literature relies on the assumption that public sector organisations will have a mission to serve the public interest, and employees will experience greater organisational commitment when they perceive congruence between their altruistic and public service values and the organisation's mission (Christensen and Wright, 2011). However, none of the existing literature has investigated the differing aspects of the organisation's mission in terms of serving the interests of specific stakeholders who benefit from public service provision, including consumers, wider society, the environment, and employees. These differing facets of the organisation's CSR can be observed and judged by employees in relation to their own personal and professional values, and thereby have implications for the level of person-organisation fit experience, and subsequent organisational commitment.

Most definitions of CSR focus on the role of the firm beyond short-term profit and shareholder value maximisation, to the impact on other primary stakeholders (e.g. customers, suppliers) and secondary stakeholders (e.g. community, environment, society in general) (De Cooman et al, 2009). Early CSR literature explored macro-level instrumental outcomes such as organisational financial and competitive performance. However, over the past two 
decades there has been a growing focus on CSR at the micro-level and the normative impact it has on employee attitudes and behaviour (Hudson et al., 2017). Micro-CSR can be defined as "the study of the effects and experiences of CSR (however it is defined) on individuals (in any stakeholder group) as examined at the individual level of analysis" (Rupp and Mallory, 2015; p.216). This stakeholder approach to CSR distinguishes between external-CSR and internal-CSR, with the former reflecting actions towards community, the physical environment and consumers (Brammer et al 2007), while the latter targets employees (Mory et al., 2016). In a recent review of such micro-CSR literature, Gond et al. (2017) found it associated with many employee outcomes including organisational commitment, job satisfaction, employee engagement, citizenship behaviour, and turnover intention.

Several theories have been put forward to help explain the relationship between CSR and organisational commitment (Gond et al., 2017). The most cited, social identity theory, assumes individuals derive their identity from the social groups in which they are members (Turner and Tajfel, 1986). People enhance their self-esteem when they perceive that the reputation and values of their organisation is in some way superior to others. A perception of relatively high CSR values can thereby result in an emotional attachment to the firm and greater organisational commitment (Brammer et al, 2007). Furthermore, while CSR values are, to a large degree, universally accepted and should thereby engender a greater level of person-organisation fit, the relationship can be expected to be stronger when employees share a similar set of ethical values (Hudson et al., 2017). Organisational justice theory also helps explain why CSR, especially with respect to internal stakeholders (i.e. employees), can be linked to increased organisational commitment (Rupp et al. 2006). Employees make judgements and develop perceptions about their organisation's internal-CSR based on the social concern embedded in the organisation's actions (procedural CSR), the outcome of these actions (distributive CSR) and how individuals are treated because of the actions 
(interactional CSR). Where employees perceive their organisation to have a high level of procedural justice, they can be expected to have greater person-organisation fit and to reciprocate in the form of organisational commitment (Brammer et al 2007). Finally, signalling theory provides insight on how organisations can use their CSR reputation, especially their observable treatment of external stakeholders, to attract recruits that value such a reputation and feel it aligns with their own personally held values.

Extant empirical evidence reports a positive relationship between perceived organisational CSR and organisational commitment. Brammer et al. (2007) used a sample of 4,712 financial services employees and found there to be a significant positive relationship between organisational commitment and both perceived internal-CSR (procedural justice and training) and external-CSR (community). Turker (2009a) also found a positive relationship between organisational commitment and aspects of external-CSR (customers, social and nonsocial stakeholders) and internal-CSR (employees) but failed to find a significant impact from another aspect of external-CSR (government). In a recent study, Hudson et al (2017) found that perceived CSR had a positive relationship with person-organisation fit and that such congruence was a significant factor in mediating the relationship between CSR and turnover intention.

In line with the above, in this study we adopt a stakeholder-based view of CSR, under which accounts staff form perceptions of their organisation's social consciousness based on how the organisation is seen to treat its internal (employee) and external (customers and wider society/environment) stakeholders. As outlined in Figure 1, we argue that employee perceptions of their organisation's CSR can moderate the relationship between individual PSM and person-organisation fit in several ways. Firstly, the reputation of the firm in terms of observable external-CSR can be expected to signal to potential recruits with high levels of PSM that the organisation shares a similar set of values. Secondly, a higher level of internal- 
CSR (organisational justice) can better enable the socialisation of employees within the organisation.

We can expect the role internal-CSR and external-CSR play in moderating this relationship to differ based upon the PSM dimension under examination. Self-sacrifice is a foundational concept representing the altruistic and prosocial aspects of PSM (Kim et al., 2013). As it represents the willingness to sacrifice personal rewards in the service of others, we can expect employees with a high level of self-sacrifice to prioritise the wellbeing of their organisation, co-workers or wider society (Kim, 2018). Such employees may develop expectations that the organisation will reciprocate by showing greater levels of internal-CSR (organisational justice), and can be expected to perceive a greater level of person-organisation fit when these reciprocal expectations are meet:

H4: Internal-CSR will moderate the relationship between self-sacrifice and personorganisation fit.

Compassion is based on identification motives and it emphasises an individual's organisational commitment to, or concern for, the needs of specific individuals and groups (Kim et al, 2013). Employees with higher levels of compassion are expected to bond with others and their organisation when they feel there is a sense of oneness in serving an identified group, such as the public, community or society (Kim, 2018). Thus, employees with a high sense of compassion will perceive a greater person-organisation fit when they feel the organisation acts with social responsibility towards external stakeholders (customers and society): 
H5: External-CSR will moderate the relationship between compassion and personorganisation fit.

As an instrumental motive, attraction to public service is concerned with the desire of employees to become involved in the public policy process and the performance of meaningful public service (Kim et al., 2013). People with high levels of this dimension are more likely to select careers in the public service when they feel opportunities to serve the public interest are provided (Kim, 2018):

H6: External-CSR will moderate the relationship between attraction to public service and person-organisation fit.

Commitment to public values is concerned with commonly held public values and the degree to which they have become internalised by staff (Kim et al., 2013). As such personal values (e.g. equality, justice) are commonly held and do not pertain to an identified group (e.g. community), firm objectives (i.e. CSR) that focus on defined internal or external stakeholders can be expected to play little or no moderating role:

H7: CSR will not moderate the relationship between commitment to public values and person-organisation fit.

\section{Methodology}

Survey data was gathered online from tax accountants and accounts administration staff working in nine separate state-owned enterprises in South Korea in $2014(\mathrm{n}=285)$. The enterprises include utilities (heating, water, rail, airport, port) and development (housing and rural development) organisations. Table 1 provides descriptive statistics of respondents. 
Most respondents are male ( 87 per cent), married ( 86 per cent) and educated to a bachelor's degree level (71 per cent). Most respondents work in either accounts administration (53 per cent) or as tax accountants (40 per cent), occupying junior (48 per cent) or lower middle management (45 per cent) grades.

\section{Insert Table 1 here}

Appendix 1 provides information on the measures used, including descriptive statistics and parameter estimates for each item utilised. All measures used a seven-point Likert-type scale (i.e. $1=$ strongly disagree to $7=$ strongly agree) and the factor loadings for the first and second order latent variables were all found to be significant $(p>.05)$.

PSM was measured using the international instrument developed by Kim et al. (2013). Perceived organisational CSR was measured using Turker (2009b)'s instrument, which addresses several stakeholder groups, including internal-CSR(employees) and external-CSR (customers and society/environment). Person-organisation fit was measured using a threeitem instrument by Cable and De Rue (2002). Organisational commitment (affective commitment)was measured using Meyer et al. (1993)'s instrument. Control variables for gender, marital status, age, tenure, qualifications and occupation were also included in each analysis. Appendix 2 provides a correlation matrix, along with descriptive statistics and a measure of reliability (Cronbach's Alpha). The reliability of each measure was found to be in excess of the 0.7 recommendation (Nunnally and Bernstein, 1994), indicating a good level of internal consistency.

The data was analysed using structural equation modelling. The analysis is divided into a mediation analysis to examine the relationship between PSM and organisational commitment, as mediated by person-organisation fit. We then use a moderated mediation analysis to examine the role perceived CSR plays in moderating the impact of PSM on person-organisation fit. In line with the Barron and Kenny (1986) approach to mediation, we 
present findings of the total, direct and indirect effects. However, given the limitations inherent in the Barron and Kenny causal steps approach, we use bootstrap estimates $(5,000$ samples) of the indirect effect with 95 percent confidence intervals (Hayes, 2009).

For the moderated mediation model, all variables were standardised to alleviate issues around nonessential multicollinearity and improve interpretability of estimates (Chin et al., 2003; Little et al., 2006). We include latent interaction terms between each form of perceived CSR and each dimension of PSM using a matched-pair product of indicators method. A bootstrap (5,000 samples) is used to estimate more precisely the standard error and parameter estimates associated with the latent variable interaction construct and their accompanying significance levels. To evaluate the effect of the interaction variable, we examine its critical values and the effect size of the change in r-squared $\left(f^{2}\right)$.

\section{Findings}

In this section we will first present the results of our mediation model, before moving on to discuss the findings of the moderated mediation model.

Table 2 shows the results of SEM analysis with person-organisation fit as a mediator in the relationship between PSM and organisational commitment. Results of a CFA for all latent variables and the control variables and found an acceptable fit with the data $\left[\chi^{2}(\mathrm{DF})=\right.$ $668.11(370), \mathrm{CFI}=.94, \mathrm{RMSEA}=.05, \mathrm{TLI}=.93]$. Five separate models were run, in turn using the second order measure for PSM and each of its first order dimensions as independent variables. As none of the control variables were found to have statistically significant coefficients when running the total effect model, they were excluded from further analysis.

\section{Insert Table 2 here}

Results for the second order PSM measure shows a significant total positive relationship with organisational commitment, thus supporting our first research hypothesis (H1). When the mediator person-organisation fit is added to the analysis, this total effect is 
found to include a statistically significant indirect relationship and a continued significant direct relationship. The bootstrap helps confirm the presence of a significant partial mediation effect, in line with our second research hypothesis $(\mathrm{H} 2)$. The remaining models on Table 2 show the dimensions of PSM most associated with public service (i.e. attraction to public service and commitment to public values) also have a significant positive relationship with organisational commitment, partially mediated by person-organisation fit. The dimensions most associated with the altruistic values of individuals (i.e. compassion and selfsacrifice) are again strongly related to organisational commitment, with the relationships being fully mediated by person-organisation fit. Our findings thereby support research hypotheses three (H3). These findings are to a large degree in line with previous research (e.g. Taylor, 2007), although unlike some of these studies we find the relationship between the PSM dimensions and organisational commitment are all at least partially mediated by person-organisation fit. Overall, we find that the level of PSM amongst accounting staff has a strong positive relationship with their organisational commitment, and a large proportion of this relationship can be explained by the level of perceived shared objectives.

Table 3 shows the results of the moderated mediation model, where we test if perceived CSR moderates the relationship between PSM and person-organisation fit. Separate results are provided for each dimension of PSM and both internal and external stakeholder CSR. To aid with interpretation, coefficients are calculated for when perceived CSR is either high or low. In line with previous research that has measured both employee values and perceived organisation values (e.g. Finegan, 2000; Stride and Higgs, 2014) our findings indicate that organisation CSR values have a more significant impact on organisational commitment than individual PSM. Bearing this in mind, we can observe some degree of interaction between many of the PSM dimensions and the level of corporate social consciousness. 


\section{Insert Table 3 here}

The mediated relationship of self-sacrifice on organisational commitment, through person-organisation fit, is found to be positively moderated by internal-CSR (employees). This finding supports our fourth research hypothesis (H4), although it should be noted that the effect size is small. As self-sacrifice represents the willingness of accounting professionals to forego personal rewards for the benefit of their organisation and co-workers, they can develop expectations regarding organisational justice and other reciprocal benefits (e.g. training, work-life balance). It is when employees perceive such internal-CSR values inform the mission and actions of their employer that they experience a greater level of person-organisation fit and organisational commitment.

The mediated relationship of both compassion and attraction to public service are found to be moderated by perceived external-CSR (society/environment). Despite the again low effect sizes, these findings are in line with our fifth and sixth research hypotheses (H5 and H6). As these dimensions of PSM are concerned with accounting professionals' desire to be involved in public service and support the needs of specific societal groups, it is when the organisation is seen to pursue the interest of wider society and the environment that employees perceive a greater level of person-organisation fit and organisational commitment. It is however interesting to note that for neither dimension of PSM is our other form of external-CSR (customers) found to have a significant moderating influence. We attribute this to the job role of accounts staff and their limited direct contact with customers.

Our results show no significant moderating influence on the mediated relationship between commitment to public values and organisational commitment, as expected under our final research hypotheses (H7). This may be a result of the value-based nature of this PSM dimension, which focuses on the internalisation of commonly held values (e.g. equality, ethics). As many of these values are personally held beliefs and are not based on a desire to 
serve specified groups or the common good, it is not surprising to see that the perceived social consciousness and actions of the organisation has less of a role to play.

In summary, our findings show that the CSR values espoused by a public service organisation are the most significant factors in determining accounting staff organisational commitment. We do however still find evidence that the PSM of accounts staff also play a significant role. Furthermore, the nature of this relationship changes depending on the dimension of PSM in question and the stakeholder being targeted by corporate social consciousness.

\section{Discussion and conclusions}

The role of accountancy in organisations concerned with the provision of public services has evolved considerably in recent decades. Pressures have derived from increased commercialisation that can be at odds with public service aims, the introduction of new professional guidance and techniques focused on stakeholder issues, and the need to facilitate information collection, analysis and dissemination to key roles within the firm. This has added to the already considerable challenges involved in recruiting and retaining accounts staff with the required training, qualifications, and experience. Aligning the interests and values of accounting professionals with those of management and the organisation, through means of selection or socialisation, can be a key step in creating a committed accountancy workforce. This paper examines this issue in the case of accounts department employees in seven Korean state-owned enterprises. More specifically, the paper addresses how individual staff PSM, which can arise both personally (e.g. compassion) or through professional training (e.g. commitment to public values), can impact on organisational commitment. We examine the role alignment of individual PSM and perceived organisational CSR objectives helps to explain this relationship, especially when such objectives include a credible commitment to 
the advancement of key internal (employee) and external (wider public, environment) stakeholder interests.

The paper's findings highlight several issues that will be of interest to managers. Findings point to the important role individual accounts staff PSM (compassion, selfsacrifice, commitment to public values, attraction to public service) play in creating a more committed workforce in public service organisations. Alongside other important criteria (e.g. qualifications, experience), such motivational factors should form part of the recruitment and retention practices of the organisation. Moreover, our findings show that it is where accounts staff perceive there to be an alignment between their PSM and the CSR objectives of their organisation, that one can expect the greater level of organisational commitment. This draws attention to the need for management to put forward a clear set of objectives and implement mechanisms (e.g. communications, empowerment) that enables employees to internalise such objectives and align them with their own individual needs. Failure by management to achieve such alignment of employee-employer objectives can lead to a sense of breach in the psychological contract and a reduced level of organisational commitment. Finally, given the focus of state-owned organisations on public service provision and the developments in accounting practices over recent decades, we find that the CSR objectives of the organisation are a particularly salient issue for employee organisational commitment in the sector. We find a credible commitment to internal organisational justice and external environmental and public interests are of importance in enhancing employees' sense of shared values and organisational commitment.

These findings have implications for the existing body of accounting research. It adds to the research on the role of personal and job/organisational characteristics in determining behavioural outcomes such as organisational commitment (e.g. Ketchand and Strawser, 2001). It also contributes to the literature on motivational differences amongst accounting 
staff who work in the public sector (e.g. Brewer and Lam, 2009; Qian et al. 2011). These are areas of accounting research that have received relatively little attention in the existing literature, and the findings of this paper should be seen as an initial step in their development. This paper highlights the role organisational undertakings towards the welfare of broadly defined internal and external stakeholders can play in creating a more committed accounting workforce. However, it does not address specific aspects of CSR (e.g. environmental sustainability, community support, diversity issues amongst employees), which should form the basis of future research. With reference to employee motivation, this paper focused on the concept of PSM and its various sub-concepts, which allowed us to distinguish between certain personally held motivations (e.g. compassion and self-sacrifice) and others that may develop through professional training and socialisation within public-sector organisations (e.g. attraction to public policy or commitment to public values). However, further research will be needed to explore employee motivation towards achievement of specified CSR goals (e.g. community volunteering, environmental sustainability), and the degree to which such motivation is passive or results in a desire to actively pursue such objectives through work duties. Finally, future research should also address governance issues (e.g. effective procedures for communicating specific organisational CSR commitments, accounting feedback mechanisms to senior management or other relevant departments) and operational issues (e.g. methods of data collection on various aspects of CSR).

Outside of existing accounting literature, the paper also contributes to the broader literature on PSM amongst public service providers. Our findings show that while employee PSM has a positive relationship with organisational commitment, employee perceptions of their organisation's CSR values are a more salient factor. While existing PSM literature has addressed issues such as mission valence (e.g. Caillier, 2016), we believe greater attention should be paid to what employees perceive to be the values that underpin their organisation's 
mission and decision-making. The values of public sector organisations should not simply be assumed to involve serving the public interest and promoting the common good, and research should instead focus more upon employee perceptions of their organisation's values.

In relation to the data and methodology adopted in this paper, we chose to focus on just one specific job type (accounts department staff) and just one type of public sector institution (state-owned enterprise). The data collected is cross-sectional and thereby cannot accurately measure causal relationships. While this approach limits the degree to which generalisations can be drawn regarding other parts of the public sector and other areas of the accounting profession, we were better able to control for differences in job and organisational characteristics. Future research would therefore benefit from longitudinal data and the application of a similar research approach to other public sector organisations and occupations.

\section{List of References}

Agudelo M.A.L., Johannsdottir L., and Davidsdottir B. (2019). "A Literature Review of the History and Evolution of Corporate Social Responsibility". InternationalJournal of Corporate Social Responsibility, Vol. 4 No. 1, pp. 1-23.

Allen N.J. and Meyer J.P. (1990). "The Measurement and Antecedents of Affective, Continuance, and Normative Commitment to the Organization". Journal of Occupational Psychology, Vol. 63 No. 1, pp. 1-18.

Anderfuhren-Biget, S., Varone, F., Giauque, D. and Ritz, A. (2010). "Motivating Employees of the Public Sector: Does Public Service Motivation Matter?". International Public Management Journal, Vol. 13 No. 3, pp. 213-246.

Ball A. (2005). "Environmental Accounting and Change in UK Local Government. Accounting", Auditing \& Accountability Journal, Vol. 18 No. 3, pp. 346-373.

Baron R.M. and Kenny D.A. (1986). "The Moderator-Mediator Variable Distinction in Social Psychological Research: Conceptual, Strategic, and Statistical Considerations". Journal of Personality and Social Psychology, Vol. 51 No. 6, pp. 1173-1182.

Bennett M., Schaltegger S. and Zvezdov D. (2013). Exploring Corporate Practices in Management Accounting for Sustainability. London: ICAEW Charitable Trusts.

Bobek D.D., Dalton D.W., Dougherty B.E., and Hageman, A.M. (2017). “An Investigation of Ethical Environments of CPAs: Public Accounting versus Industry". Behavioral Research in Accounting, Vol. 29 No. 1, pp. 43-56. 
Bracci E., Humphrey C., Moll J., and Steccolini I. (2015). "Public Sector Accounting, Accountability and Austerity: More than Balancing the Books?" Accounting, Auditing \& Accountability Journal, Vol. 28 No. 6, pp. 878-908.

Brammer S., Millington A. and Rayton B. (2007). "The Contribution of Corporate Social Responsibility to Organizational Commitment". International Journal of Human Resource Management, Vol. 18 No. 10, pp. 1701-1719.

Brewer B. and Lam G.K.Y. (2009). "Conflict Handling Preferences: A Public-Private Comparison." Public Personnel Management, Vol. 38 No. 3, pp. 1-14.

Bright L. (2013). "Where Does Public Service Motivation Count the Most in Government Work Environments? A Preliminary Empirical Investigation and Hypotheses." Public Personnel Management, Vol. 42 No. 1, pp. 5-26.

Brockhaus S. Fawcett S.E., Knemeyer AM, and Fawcett, A.M.. (2017). "Motivation s for Environmental and Social Consciousness: Reevaluating the Sustainability-based View." Journal of Cleaner Production, Vol. 143 No. 1, pp. 933-947.

Cable D. and De Rue D. (2002). "The Convergent and Discriminant Validity of Subjective Fit Perceptions." Journal of Applied Psychology, Vol. 87 No. 5, pp. 875-884.

Caillier J.G. (2016). "Do Transformational Leaders Affect Turnover Intentions and Extra-Role Behaviors Through Mission Valence?" The American Review of Public Administration, Vol. 46 No. 2, pp. 226-242.

Castaing S. (2006). "The Effects of Psychological Contract Fulfillment and Public Service Motivation on Organizational Commitment in the French Civil Service." Public Policy and Administration, Vol. 21 No. 1, pp. 84-98.

Chatman J.A. (1991). "Matching People and Organizations: Selection and Socialization in Public Accounting Firms." Administrative Science Quarterly, Vol. 36 No. 3, pp. 459-484.

Chin W.W., Marcolin B.L. and Newsted P.R. (2003). "A Partial Least Squares Latent Variable Modeling Approach for Measuring Interaction Effects: Results from a Monte Carlo Simulation Study and an Electronic-Mail Emotion/Adoption Study." Information Systems Research, Vol. 14 No. 2, pp. 189-217.

Christensen R.K. and Wright B.E. (2011). "The Effects of Public Service Motivation on Job Choice Decisions: Disentangling the Contributions of Person-Organization Fit and Person-Job Fit." Journal of Public Administration Research \& Theory, Vol. 21 No. 4, pp. 723-743.

Collins E., Lawrence S., Roper J., and Haar, J. (2011). Sustainability and the Role of the Management Accountant. London: Chartered Institute of Management Accountants. Available at: http://www.cimaglobal.com/ (accessed: 25th Oct. 2020)

Coursey D., Yang K. and Pandey S.K. (2012). "Public Service Motivation (PSM) and Support for Citizen Participation: A Test of Perry and Vandenabeele's Reformulation of PSM Theory." Public Administration Review, Vol. 72 No. 4, pp. 572-582.

Coyle-Shapiro J.A.-M. and Kessler K. (2003). "The Employment Relationship in the U.K. Public Sector: A Psychological Contract Perspective." Journal of Public Administration Research and Theory, Vol. 13 No. 2, pp. 213-230.

Curtis M.B. and Taylor E.Z. (2018). "Developmental Mentoring, Affective Organizational Commitment, and Knowledge Sharing in Public Accounting Firms." Journal of Knowledge Management, Vol. 22 No. 1, pp. 142-161.

De Cooman R., Gieter S.D., Pepermans R., Hermans, S., Du Bois, C., Caers, R. and Jegers M. (2009). "Person-Organization Fit: Testing Socialization and Attraction-Selection-Attrition Hypotheses." Journal of Vocational Behavior, Vol. 74 No. 1, pp. 102-107. 
Dittenhofer M.A. (2001). "Behavioral Aspects of Government Financial Management." Managerial Auditing Journal, Vol. 16 No. 8, pp. 451-457.

Farneti F. and Guthrie J. (2009). "Sustainability Reporting by Australian Public Sector Organisations: Why they Report?" Accounting Forum, Vol. 33 No. 2, pp. 89-98.

Finegan J.E. (2000). "The Impact of Person and Organizational Values on Organizational Commitment." Journal of Occupational \& Organizational Psychology, Vol. 73 No.2, pp. 149-169.

Gond J.P., El Akremi A., Swaen V., and Babu N.. (2017). "The Psychological Microfoundations of Corporate Social Responsibility: A Person-Centric Systematic Review." Journal of Organizational Behavior, Vol. 38 No. 2, pp. 225-246.

Gray R., Walters D., Bebbington J., and Thompson, I. (1995). "The Greening of Enterprise: An Exploration of the (Non) Role of Environmental Accounting and Environmental Accountants in Organisational Change." Critical Perspectives on Accounting, Vol. 6 No. 3, pp. 211-239.

Harari M.B., Herst D.E.L., Parola H.R., and Carmona, B.P. (2017). "Organizational Correlates of Public Service Motivation: A Meta-analysis of Two Decades of Empirical Research." Journal of Public Administration Research \& Theory, Vol. 27 No. 1, pp. 68-84.

Hayes A.F. (2009). "Beyond Baron and Kenny: Statistical Mediation Analysis in the New Millennium." Communication Monographs, Vol. 76 No. 4, pp. 408-420.

Houston D.J. (2000). "Public-Service Motivation: A Multivariate Test." Journal of Public Administration Research \& Theory, Vol. 10 No. 4, pp. 713-728.

Hudson S., Bryson D. and Michelotti M. (2017). "Individuals' Assessment of Corporate Social Performance, Person-Organization Values and Goals Fit, Job Satisfaction and Turnover Intentions." Industrial Relations, Vol. 72 No. 2, pp. 322-344.

IIRC (2020). "When? Advocate for Global Adoption. International Integrated Reporting Council." Available at: https://integratedreporting.org/when-advocate-for-global-adoption/ (accessed: 25 Oct. 2020).

Kaur A. and Lodhia, S. (2018). "Stakeholder Engagement in Sustainability Accounting and Reporting: A Study of Australian Local Councils." Accounting, Auditing \& Accountability Journal, Vol. 31 No. 1, pp. 338-368.

Kelly, Mand Alam, M. (2008). "Management Accounting and the Stakeholder Value Model." Journal of Applied Management Accounting Research, Vol. 6 No. 1, pp. 75-86.

Ketchand A.A. and Strawser J.R. (2001). "Multiple Dimensions of Organisational Commitment: Implications for Future Accounting Research." Behavoral Research in Accounting, Vol. 21 No. 1, pp. 221-251.

Kim S. (2017). "Comparison of a Multidimensional to a Unidimensional Measure of Public Service Motivation: Predicting Work Attitudes." International Journal of Public Administration, Vol. 40 No. 6, pp. 504-515.

Kim S. (2018). "Public Service Motivation, Organizational Social Capital, and Knowledge Sharing in the Korean Public Sector." Public Performance \& Management Review, Vol. 41 No. 1, pp. 130-151.

Kim S., Vandenabeele W., Wright B.E., Bøgh Andersen, L., Cerase, F.P., Christensen, R.K. Desmarais, C., Koumenta,M., Leisink, P., Bangcheng, L., Palidauskaite, J., Pedersen, L.H., Perry, J.L., Ritz, A., Taylor, J., and De Vivo, P. (2013). "Investigating the Structure and Meaning of Public Service Motivation across Populations: Developing an International Instrument and Addressing Issues of Measurement Invariance." Journal of Public Administration Research \& Theory, Vol. 23 No. 1, pp. 79102. 
Kristof A. (1996). "Person-Organization Fit: An Integrative Review of its Conceptualizations, Measurement, and Implications." Personnel Psychology, Vol. 49 No. 1, pp. 1-49.

Little T.D, Bovaird J.A and Widaman K.F. (2006). "On the Merits of Orthogonalizing Powered and Product Terms: Implications for Modeling Interactions among Latent Variables." Structural Equation Modeling, Vol. 13 No. 4, pp. 497-519.

McManus, L., Subramaniam, N. and Monroe, G. (2014). "Organisational and Professional Commitment of Early Career Accountants: Do Mentoring and Organisational Ethical Climate Matter?" Accounting \& Finance, 54: 1231-1261

Meyer J.P. and Allen N.J. (1991). "A Three-Component Conceptualization of Organisational Commitment." Human Resource Management Review, Vol. 1 No. 1, pp. 61-89.

Meyer J.P., Allen N.J. and Smith C. (1993). "Commitment to Organizations and Occupations: Extension and Test of a Three-component Conceptualization." Journalof Applied Psychology, Vol. 78 No. 4, pp. 538-551.

Meyer J.P., Stanley D.J., Herscovitch L., and Topolnytsky, L. (2002). "Affective, Continuance and Normative Commitment to the Organization: A Meta-analysis of Antecedents, Correlates, and Consequences." Journal of Vocational Behavior, Vol. 61 No. 1, pp. 20-52.

Mory L., Wirtz B.W. and Göttel V. (2016). "Factors of Internal Corporate Social Responsibility and the Effect on Organizational Commitment." International Journal of Human Resource Management, Vol. 27 No. 13 , pp. 1393-1425.

Moynihan D.P. and Pandey S.K. (2007). "Finding Workable Levers Over Work Motivation: Comparing Job Satisfaction, Job Involvement, and Organizational Commitment." Administration \& Society, Vol. 39 No. 7, pp. 803-832.

Nunnally J.C. and Bernstein I.H. (1994). Psychometric Theory, New York: McGraw Hill.

Olson O., Humprey C. and Guthrie J. (2001). "Caught in an Evaluatory Trap: A Dilemma for Public Service under NPFM." The European Accounting Review, Vol. 10 No. 3, pp. 505-522.

Palma R. (2016). "Public Service Motivation and Employee Outcomes in the Italian Public Sector: Testing the Mediating effect of Person-Organisation Fit." Journal of Applied Quantitative Methods, 11: 1-16.

Perry J.L. (1996). "Measuring Public Service Motivation: An Assessment of Construct Reliability and Validity." Journal of Public Administration Research \& Theory, Vol. 6 No. 1, pp. 5-22.

Perry J.L. and Wise L.R. (1990). "The Motivational Bases of Public Service." Public Administration Review, Vol. 50 No. 3, pp. 367-373.

Qian W., Burritt R.L. and Monroe G.S. (2011). "Environmental Management Accounting in Local Government : A Case of Waste Management." Accounting, Auditing \& Accountability Journal, Vol. 24 No. January, pp. 93-128.

Rousseau D.M. (1995). Psychological contracts in organizations: understanding written and unwritten agreements. Newbury Park, CA: Sage.

Ribeiro V.P., Aibar-Guzmán C., Aibar-Guzman B., and da Silva Monteiro, S.A. (2016). "Determinants of Environmental Accounting and Reporting Practices in Portuguese Local Entities." Corporate Communications: An International Journal, Vol. 21 No. 3, pp. 352-370.

Rupp D.E. and Mallory D.B. (2015). “Corporate Social Responsibility: Psychological, Person-Centric, and Progressing." Annual Review of Organizational Psychology and Organizational Behavior, Vol. 2 No. 1, pp. 211-236. 
Rupp D.E., Ganapathi, J., Aguilera R.V., and Williams C.A. (2006). "Employee Reactions to Corporate Social Responsibility: An Organizational Justice Framework." Journal of Organisational Behaviour, Vol. 27 No. 4, pp. 537-543.

Schaltegger, S. and Burritt, R. (2000). Contemporary EnvironmentalAccounting, Greenleaf: Sheffield. Schaltegger S. and Zvezdov D. (2015). "Gatekeepers of Sustainability Information: Exploring the Roles of Accountants." Journal of Accounting \& Organizational Change, Vol. 11 No. 3, pp. 333-361.

SchalteggerS., Burritt R., Zvezdov D., Hörisch, J. and Tingey-Holyoak, J. (2015). "Management Roles and Sustainability Information. Exploring Corporate Practice." Australian Accounting Review, Vol. 75 No. 4, pp. 328-345.

Shafer W. (2015). "Ethical Climate, Social Responsibility, and Earnings Management." Journal of Business Ethics, Vol. 126 No. 1, pp. 43-60.

Smith, D. and Hall, M. (2008). "An Empirical Examination of a Three-Component Model of Professional Commitment among Public Accountants." Behavioral Research in Accounting, Vol. 20 No. 1, pp. 75-92.

Steijn B. (2008). "Person-Environment Fit and Public Service Motivation." International Public Management Journal, Vol. 11 No. 1, pp. 13-27.

Street D.L. and Bishop A.C. (1991). "An Empirical Examination of the Need Profiles of Profe ssional Accountants." Behavioral Research in Accounting, Vol. 3 No. 1, pp. 97-116.

Stride H. and Higgs M. (2014). "An Investigation into the Relationship Between Values and Commitment: A Study of Staff in the U.K. Charity Sector." Nonprofit and Voluntary Sector Quarterly, Vol. 43 No. 3, pp. 455-479.

Taylor J. (2007). "The Impact of Public Service Motives on Work Outcomes in Australia: A Comparative Multi-dimensional Analysis." Public Administration, Vol. 85 No. 4, pp. 931-959.

Teo S.T.T., Pick D., Xerri M., and Newton, C. (2016). "Person-Organization Fit and Public Service Motivation in the Context of Change." Public Management Review, Vol. 18 No. 5, pp. 740-762.

Turker D. (2009a). "How Corporate Social Responsibility Influences Organizational Commitment." Journal of Business Ethics, Vol. 89 No. 2, pp. 189-204.

Turker D. (2009b). "Measuring Corporate Social Responsibility: A Scale Development Study." Journal of Business Ethics, Vol. 85 No. 4, pp. 411-427.

Turner J.C. and Tajfel H. (1986). "The Social Identity Theory of Intergroup Behavior." In: Austin S.W.W.G. (Ed). Psychology of Intergroup Relations, 2nd ed. Chicago: Nelson-Hall, pp. 7-24.

Wright B.E. and Pandey S.K. (2008). "Public Service Motivation and the Assumption of PersonOrganization Fit Testing the Mediating Effect of Value Congruence." Administration \& Society, Vol. 40 No. 5, pp. 502-521.

Wright B.E. and Christensen R.K. (2010). "Public Service Motivation: A Test of the Job AttractionSelection-Attrition Model." International Public Management Journal, Vol. 13 No. 2, pp. 155-176.

Yang Z., Sun J., Zhang Y., Wang, Y. and Cao, L. (2017). "Employees' Collaborative use of Green Information Systems for Corporate Sustainability: Motivation, Effort and Performance." Information Technology for Development, Vol. 23 No. 3, pp. 486-506. 
Figure 1: PSM and organisational commitment, as influenced by CSR

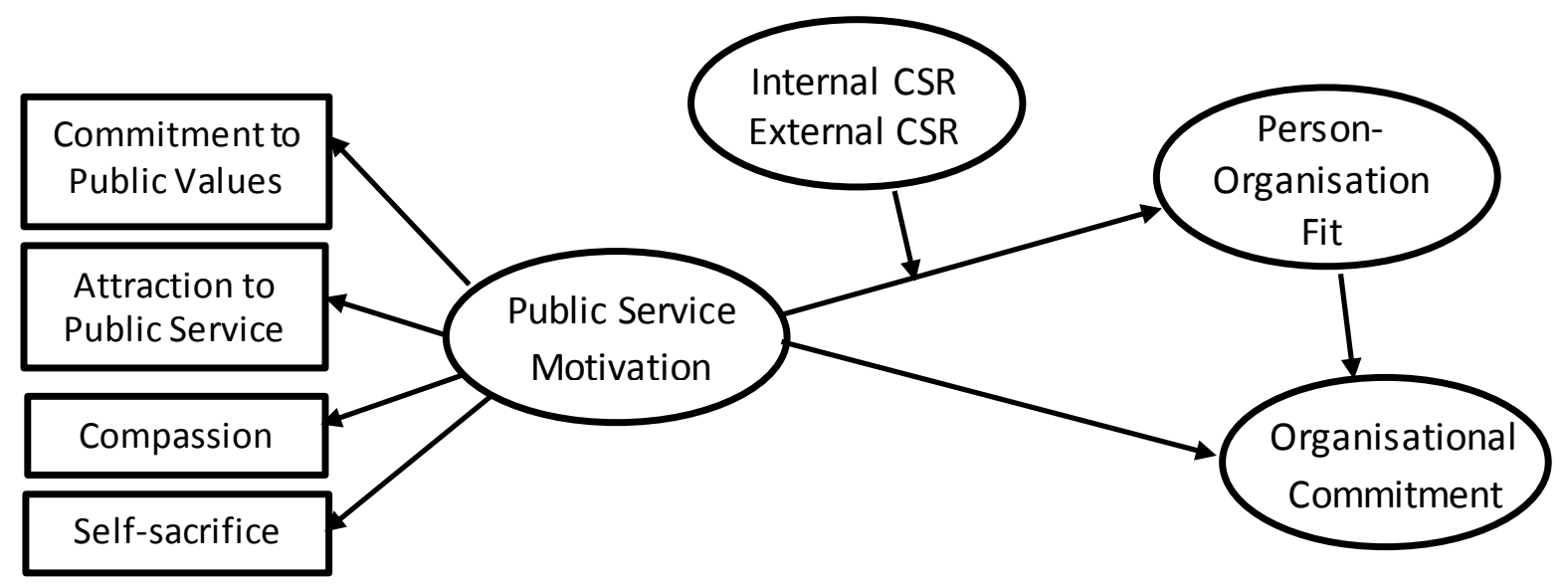




\begin{tabular}{|c|c|c|c|}
\hline Variable & Percentage & Variable & Percentage \\
\hline Gender & & Occupation group & \\
\hline Male & 87.4 & Administration & 52.7 \\
\hline Female & 12.6 & Tax accountant & 39.6 \\
\hline Marital Status & & Other & 7.7 \\
\hline Unmarried & 14.4 & Company & \\
\hline Married & 85.6 & KDHC (district heating) & 6.0 \\
\hline & & Kwater (water utility) & 16.2 \\
\hline Academic qualification & & Korail (railway) & 17.9 \\
\hline $\begin{array}{l}\text { High school } \\
\text { College }\end{array}$ & 2.5 & KRC (agri. infrastructure) & 10.5 \\
\hline College & 2.8 & IIAC (airport operator) & 7.7 \\
\hline Bachelor degree & 71.2 & BPA (port authority) & 10.5 \\
\hline Masters & 18.9 & EX (electricity utility) & 8.4 \\
\hline Doctorate & 4.6 & KHGC (housing finance) & 11.6 \\
\hline Seniority in firm & & LH (housing development) & 11.2 \\
\hline Junior grade & 47.6 & & \\
\hline Lower middle mgt. & 45.3 & & Mean (SD) \\
\hline Middle mgt. & 6.7 & Tenure (months) & $11.8(7.6)$ \\
\hline Upper mgt. & 0.4 & Age (years) & $41.0(6.1)$ \\
\hline
\end{tabular}




\begin{tabular}{lccccc}
\hline \multicolumn{7}{c}{ PSM } & SS & COM & APS & CPV \\
\hline Gender & $.024(.054)$ & $.034(.052)$ & $.029(.053)$ & $.028(.053)$ & $.034(.054)$ \\
Marital & $.032(.063)$ & $.049(.061)$ & $.048(.059)$ & $.038(.063)$ & $.037(.063)$ \\
Age & $-.002(.098)$ & $.003(.097)$ & $-.001(.098)$ & $-.004(.098)$ & $.027(.096)$ \\
Tenure & $.058(.072)$ & $.044(.072)$ & $.050(.073)$ & $.053(.071)$ & $.033(.071)$ \\
Qualification & $.033(.048)$ & $.049(.048)$ & $.040(.047)$ & $.035(.047)$ & $.027(.051)$ \\
Seniority & $-.031(.055)$ & $-.009(.056)$ & $-.017(.054)$ & $-.021(.055)$ & $-.044(.055)$ \\
Total effect & $.432(.120)^{* * *}$ & $.356(.062)^{* * *}$ & $.244(.088)^{* *}$ & $.413(.069)^{* * *}$ & $.329(.074)^{* * *}$ \\
P-O fit & $.404(.070)^{* * *}$ & $.762(.052)^{* * *}$ & $.753(.047)^{* * *}$ & $.713(.054)^{* * *}$ & $.732(.048)^{* * *}$ \\
Direct effect & $.146(.063)^{*}$ & $.012(.057)$ & $.063(.063)$ & $.146(.064)^{*}$ & $.148(.053)^{* *}$ \\
Indirect effect & $.286(.055)^{* * *}$ & $.344(.050)^{* * *}$ & $.181(.063)^{* *}$ & $.266(.052)^{* * *}$ & $.181(.051)^{* * *}$ \\
CI (95\%) & $(.209, .584)$ & $(.223, .426)$ & $(.046, .314)$ & $(.190, .515)$ & $(.113, .452)$ \\
\hline Model R ${ }^{2}$ & .608 & .590 & .594 & .608 & .611 \\
$\chi^{2}$ (DF) & $563.77(264)$ & $135.44(60)$ & $96.69(61)$ & $101.59(60)$ & $89.457(61)$ \\
CFI & .934 & .974 & .986 & .984 & .988 \\
RMSEA & .064 & .067 & .045 & .049 & .041 \\
TLI & .925 & .966 & .983 & .979 & .985 \\
Notes: standardised coefficients, standard errors given in parentheses, * p <.05, ** p < .01, *** p < \\
.001, PSM (Public Service Motivation); CPV (Commitment to Public Values); APS (Attraction to \\
Public Service); COM(Compassion); SS (Self-sacrifice); P-O Fit (Person-Organisation Fit) \\
..
\end{tabular}




\begin{tabular}{|c|c|c|c|c|c|c|c|c|}
\hline$\overline{\text { PSM }}$ & $\overline{\mathrm{CSR}}$ & IV & MV & Interaction & $\Delta R^{2}\left(f^{2}\right)$ & $\begin{array}{c}\text { CI } \\
(95 \%)\end{array}$ & High & Low \\
\hline \multirow{6}{*}{ SS } & CSR & $.180 * *$ & .489 *** & .072 & .007 & -.097 & $.259 *$ & .102 \\
\hline & (soc./envir.) & $(.093)$ & $(.084)$ & (.096) & $(.017)$ & .318 & $(.108)$ & $(.091)$ \\
\hline & CSR & $.113^{*}$ & $.670 * * *$ & .080 & .027 & -.071 & .171 & .058 \\
\hline & (cus.) & $(.153)$ & $(.075)$ & $(.058)$ & $(.066)$ & .229 & $(.091)$ & $(.086)$ \\
\hline & CSR & .010 & $.764 * * *$ & $.103 *$ & .009 & .046 & $.178^{*}$ & .059 \\
\hline & (emp.) & $(.073)$ & $(.136)$ & (.109) & $(.023)$ & 249 & $(.077)$ & $(.080)$ \\
\hline \multirow{6}{*}{$\mathrm{COM}$} & CSR & .019 & $.563 * * *$ & $.143^{*}$ & .010 & .067 & $.187^{*}$ & -.080 \\
\hline & (soc./envir.) & $(.032)$ & $(.081)$ & $(.115)$ & $(.025)$ & .734 & $(.090)$ & $(.172)$ \\
\hline & CSR & -.027 & $.740 * * *$ & .065 & .027 & -.106 & .037 & -.106 \\
\hline & (cus.) & $(.098)$ & $(.073)$ & $(.115)$ & $(.067)$ & .461 & $(.102)$ & $(.167)$ \\
\hline & CSR & -.003 & $.770 * * *$ & .027 & .006 & -.164 & .022 & -.031 \\
\hline & (emp.) & $(.085)$ & $(.126)$ & $(.080)$ & $(.015)$ & .210 & $(.078)$ & $(.090)$ \\
\hline \multirow[t]{6}{*}{$\overline{\text { APS }}$} & CSR & .049 & $.515 * * *$ & $.193^{* * *}$ & 0.01 & .084, & $.233^{*}$ & -.086 \\
\hline & (soc./envir.) & $(.088)$ & $(.094)$ & $(.097)$ & $(.026)$ & .557 & (.109) & $(.081)$ \\
\hline & CSR & -.099 & $.790 * * *$ & .096 & .031 & -.049 & -.006 & $-.143 *$ \\
\hline & (cus.) & $(.085)$ & $(.092)$ & (.073) & (.079) & .292 & $(.098)$ & $(.076)$ \\
\hline & CSR & .025 & $.766 * * *$ & -.018 & .004 & -.235 & .004 & .034 \\
\hline & (emp.) & $(.063)$ & $(.132)$ & $(.074)$ & $(.010)$ & .151 & $(.084)$ & $(.070)$ \\
\hline \multirow[t]{5}{*}{ CPV } & CSR & -.069 & $.593 * * *$ & .087 & .012 & -.215 & .087 & -.106 \\
\hline & (soc./envir.) & $(.138)$ & (.094) & $(.153)$ & $(.031)$ & .717 & $(.281)$ & $(.142)$ \\
\hline & CSR & $-.225^{*}$ & $.870 * * *$ & .077 & .035 & -.138 & -.179 & - \\
\hline & (cus.) & $(.122)$ & $(.091)$ & $(.080)$ & (.090) & .371 & $(.222)$ & $.303^{* *}$ \\
\hline & $\begin{array}{l}\text { CSR } \\
\text { (emp.) }\end{array}$ & $\begin{array}{l}-.072 \\
(.096)\end{array}$ & $\begin{array}{c}.802 * * * \\
(.134)\end{array}$ & $\begin{array}{l}-.008 \\
(.125)\end{array}$ & $\begin{array}{c}.003 \\
(.008)\end{array}$ & $\begin{array}{c}-.989 \\
.309\end{array}$ & $\begin{array}{l}-.086 \\
(.396)\end{array}$ & $\begin{array}{l}-.067 \\
(.208)\end{array}$ \\
\hline \multicolumn{9}{|c|}{$\begin{array}{l}\text { Notes: standardised coefficients, standard errors given in parentheses, IV }=\text { independent variable, MV }= \\
\text { moderating variable, Effect size }\left(f^{2}\right)=\left[\mathrm{R}^{2} \text { (interaction model) }-\mathrm{R}^{2} \text { (main effects model)]/[1- } \mathrm{R}^{2} \text { (main }\right. \\
\text { effects model)], High/Low }=[\mathrm{IV} \beta+(\text { interaction } \beta+/-1 \mathrm{SD}) * \text { mediation } \beta], * \mathrm{p}<.05, * * \mathrm{p}<.01, * * * \mathrm{p}< \\
\text {.001, PSM (Public Service Motivation); CPV (Commitment to Public Values); APS (Attraction to Public } \\
\text { Service); COM (Compassion); SS (Self-sacrifice); CSR (Corporate Social Responsibility); P-O Fit } \\
\text { (Person-Organisation Fit); OC (Organisational Commitment), soc./envir (society/environment); emp. } \\
\text { (employee); cus. (customer). }\end{array}$} \\
\hline
\end{tabular}




\begin{tabular}{|c|c|c|c|c|}
\hline Variables & Items of measure & $\mathrm{M}$ & $\mathrm{SD}$ & FL \\
\hline $\begin{array}{l}\text { Attraction to } \\
\text { public service }\end{array}$ & $\begin{array}{l}\text { APS1: I admire people who initiate or are involved in activities to } \\
\text { aid my community. } \\
\text { APS2: It is important to contribute to activities that tackle social } \\
\text { problems. } \\
\text { APS3: Meaningful public service is very important to me. } \\
\text { APS4: It is important for me to contribute to the common good. }\end{array}$ & $\begin{array}{l}4.48 \\
4.41 \\
4.25\end{array}$ & $\begin{array}{l}.73 \\
.59 \\
.64 \\
.69\end{array}$ & $\begin{array}{l}.61 \\
.64 \\
.73 \\
.80\end{array}$ \\
\hline $\begin{array}{l}\text { Commitment } \\
\text { to public } \\
\text { values }\end{array}$ & $\begin{array}{l}\text { CPV1: I think equal opportunities for citizens are very important. } \\
\text { CPV2: It is important that citizens can rely on the continuous } \\
\text { provision of public services. } \\
\text { CPV3: It is fundamental that the interests of future generations are } \\
\text { taken into account when developing public policies. } \\
\text { CPV4: To act ethically is essentialfor public servants. }\end{array}$ & $\begin{array}{l}4.56 \\
4.36 \\
4.62 \\
4.75\end{array}$ & $\begin{array}{l}.59 \\
.68 \\
.59 \\
.49\end{array}$ & $\begin{array}{l}.68 \\
.68 \\
.66 \\
.55\end{array}$ \\
\hline Compassion & $\begin{array}{l}\text { COM1: I feel sympathetic to the plight of the underprivileged. } \\
\text { COM2: I empathize with other people who face difficulties. } \\
\text { COM3: I get very upset when I see other people being treated } \\
\text { unfairly. } \\
\text { COM4: Considering the welfare of others is very important }\end{array}$ & $\begin{array}{l}4.26 \\
4.24 \\
4.28 \\
4.30\end{array}$ & $\begin{array}{l}.77 \\
.71 \\
.72 \\
.67\end{array}$ & $\begin{array}{l}.81 \\
.89 \\
.79 \\
.54\end{array}$ \\
\hline Self-sacrifice & $\begin{array}{l}\text { SS1: I am prepared to make sacrifices for the good of society. } \\
\text { SS2: I believe in putting civic duty before self. } \\
\text { SS3: I am willing to risk personal loss to help society. } \\
\text { SS4: I would agree to a good plan to make a better life for the poor, } \\
\text { even if it costs me money. }\end{array}$ & $\begin{array}{l}3.80 \\
3.76 \\
3.65\end{array}$ & $\begin{array}{l}.83 \\
.84 \\
.87 \\
.81\end{array}$ & $\begin{array}{l}.90 \\
.82 \\
.86 \\
.76 \\
\end{array}$ \\
\hline $\begin{array}{l}\text { Public } \\
\text { Service } \\
\text { Motivation }\end{array}$ & $\begin{array}{l}\text { Attraction to public service } \\
\text { Commitment to public values } \\
\text { Compassion } \\
\text { Self-sacrifice }\end{array}$ & - & $\begin{array}{l}- \\
-\end{array}$ & $\begin{array}{l}.96 \\
.86 \\
.57 \\
.60 \\
\end{array}$ \\
\hline $\begin{array}{l}\text { CSR - } \\
\text { Society/ } \\
\text { environment }\end{array}$ & $\begin{array}{l}\text { STK1: I think my company participates in activities which aim to } \\
\text { protect and improve the quality of the natural environment. } \\
\text { STK2: I think my company makes investment to create a better life } \\
\text { for future generations. } \\
\text { STK3: I think my company supports nongovernmental } \\
\text { organizations working in problematic areas. } \\
\text { STK4: I think my company contributes to campaigns and projects } \\
\text { that promote the well-being of the society. }\end{array}$ & $\begin{array}{l}4.00 \\
3.98 \\
3.73 \\
3.97\end{array}$ & $\begin{array}{l}.84 \\
.89 \\
.90 \\
.82\end{array}$ & $\begin{array}{l}.76 \\
.75 \\
.85 \\
.87\end{array}$ \\
\hline $\begin{array}{l}\text { CSR - } \\
\text { Customer }\end{array}$ & $\begin{array}{l}\text { CUS1: Our company respects consumer rights beyond the legal } \\
\text { requirements. } \\
\text { CUS2: Our company provides full and accurate information about } \\
\text { its products to its customers } \\
\text { CUS3: Customer satisfaction is highly important for our company. }\end{array}$ & $\begin{array}{l}3.90 \\
3.91 \\
4.41\end{array}$ & $\begin{array}{l}.86 \\
.77 \\
.65\end{array}$ & $\begin{array}{l}.82 \\
.80 \\
.62\end{array}$ \\
\hline $\begin{array}{l}\text { CSR - } \\
\text { Employee }\end{array}$ & $\begin{array}{l}\text { EMP1: I think my company supports employees who want to } \\
\text { acquire additional education and improve job skills and career. } \\
\text { EMP2: I think my company implements flexible policies to provide } \\
\text { a good work \& life balance for its employees. } \\
\text { EMP3: I think the management of my company is primarily } \\
\text { concerned with employees' needs and wants. } \\
\text { EMP4: I think managerial decisions related with the employees are } \\
\text { usually fair. }\end{array}$ & 3.53 & $\begin{array}{l}.86 \\
.88 \\
.98 \\
.87\end{array}$ & $\begin{array}{l}.63 \\
.73 \\
.87 \\
.89\end{array}$ \\
\hline $\begin{array}{l}\text { Person- } \\
\text { organisation- } \\
\text { fit }\end{array}$ & $\begin{array}{l}\text { POF1: The things that I value in life are very similar to the things } \\
\text { that my organization values } \\
\text { POF2: My personal values match my organization's values and } \\
\text { culture } \\
\text { POF3: My organization's values and culture provide a good fit with } \\
\text { the things that I value in life }\end{array}$ & $\begin{array}{l}3.63 \\
3.66 \\
\end{array}$ & $\begin{array}{l}.83 \\
.87 \\
.82\end{array}$ & $\begin{array}{l}.87 \\
.91 \\
.94\end{array}$ \\
\hline
\end{tabular}




\begin{tabular}{|c|c|c|c|c|}
\hline Variables & Items of measure & $\mathrm{M}$ & SD & $\overline{\text { FL }}$ \\
\hline $\begin{array}{l}\text { Affective } \\
\text { (Organisational) }\end{array}$ & $\begin{array}{l}\text { AC1: I would be very happy to spend the rest of my career in } \\
\text { this organisation }\end{array}$ & 3.94 & .80 & .83 \\
\hline \multirow[t]{6}{*}{ Commitment } & AC2: I really feel as if this organization's problems are my own & & & \\
\hline & $\begin{array}{l}\text { AC3: I would find it difficult to become as attached to another } \\
\text { organisation as I am to this one }\end{array}$ & 3.93 & .83 & .86 \\
\hline & AC4: I feel like 'part of the family' at my organisation & 3.70 & .90 & .63 \\
\hline & $\begin{array}{l}\text { AC5: This organisation has a great deal of personal meaning for } \\
\text { me }\end{array}$ & 3.95 & .77 & .89 \\
\hline & AC6: I feel a strong sense of belonging to my organisation & 4.24 & .72 & .78 \\
\hline & & 4.12 & .79 & .80 \\
\hline
\end{tabular}

Appendix 1.

Notes: mean values (M), standard deviation (SD), factor loading (FL). 


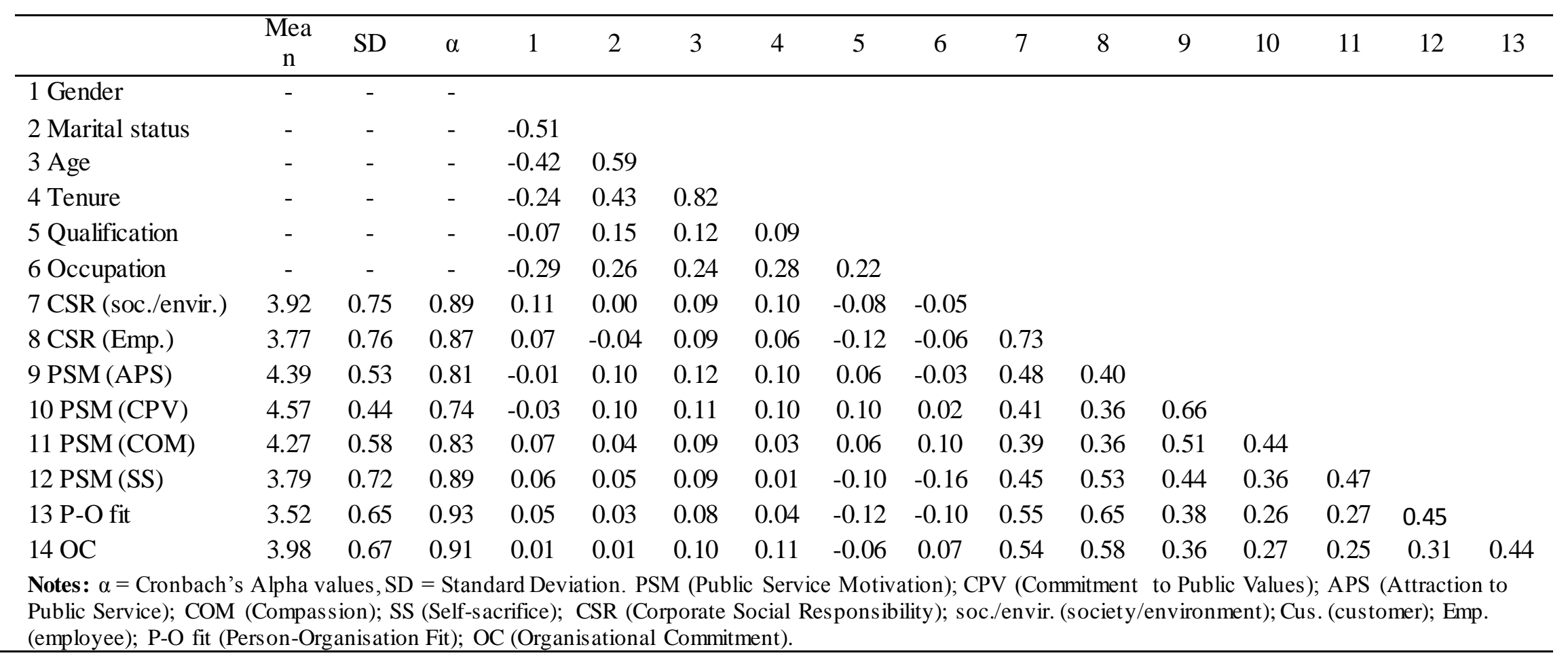

